\title{
Kapitał społeczny jako determinanta przedsiębiorczości etnicznej wśród białoruskich imigrantów w Polsce
}

\author{
Social capital as a determinant of ethnic entrepreneurship among \\ Belarusian immigrants in Poland
}

\section{Wprowadzenie}

Zagadnienia dotyczące przedsiębiorczości ${ }^{1}$ jak i migracji są przedmiotem wielu badań różnych dyscyplin naukowych ze względu na interdyscyplinarny charakter tych kwestii. Powyższe zagadnienia zajmują w XXI w. istotne miejsce w dyskusjach naukowych, gospodarczych i politycznych. Państwa poprzez odpowiednie opracowanie polityki migracyjnej starają się kontrolować ruchy wędrówkowe społeczeństwa oraz wykorzystywać potencjał napływającej ludności. Przyjmując założenie, że podstawą zjawisk migracyjnych są uwarunkowania ekonomiczne oraz chęć poprawy bytu, to sposób wyboru miejsca docelowego, zwłaszcza gdy przyjmuje stabilną i dużą skalę, pozostaje nadal kwestią otwartą. Interesujące okazuje się również zagadnienie adaptacji przybyszy w nowym społeczeństwie $\mathrm{z}$ uwagi na ich status mniejszości narodowej lub etnicznej w stosunku do rdzennych obywateli państwa przyjmującego. Należy zwrócić uwagę na sposób przezwyciężenia barier integracyjnych w nowym środowisku, pojawiających się w wyniku braku znajomości języka, lokalnych przepisów i zasad. Jest to również przesłanka do wykluczenia imigrantów z rynku pracy lub bariera do pozyskania stanowiska odpowiadającego kwalifikacjom. W celu zminimalizowania ryzyka $\mathrm{w}$ procesie zmiany miejsca zamieszkania przyby-

1 W literaturze przedmiotu przedsiębiorczość jest definiowana jako gotowość i zdolność do podejmowania i rozwiązywania w sposób twórczy i nowatorski nowych problemów, umiejętność wykorzystania pojawiających się szans i okazji oraz elastycznego przystosowywania się do zmieniających się warunków (Kwarcińska, 2004, s. 15). 
sze są wspierani przez społeczeństwo etniczne, które dostarcza niezbędnych informacji, niekiedy wsparcia finansowego lub pozamaterialnego. Migranci również mogą liczyć na pomoc w poszukiwaniu pracy lub atrakcyjnych nisz biznesowych, które są nastawione na zaspokojenie potrzeb przebywających w kraju rodaków. Takie relacje nie byłyby możliwe bez wzajemnego zaufania, aktywnych relacji międzyludzkich oraz wspólnych wartości, które tworzą kapitał społeczny. W związku z tym celem artykułu jest ustalenie sposobu oddziaływania kapitału społecznego na rozwój przedsiębiorczości etnicznej wśród białoruskich imigrantów w Polsce. Pierwsza część artykułu prezentuje zagadnienia dotyczące kapitału społecznego imigrantów oraz uwarunkowania, które wpływają na jego kształtowanie. Następnie autorzy przybliżą tematykę przedsiębiorczości etnicznej oraz przedstawią wyniki badań realizowanych wśród białoruskich imigrantów, którzy podjęli działalność gospodarczą na rynku etnicznym w Polsce w latach 2011-2020.

\section{Teoretyczne aspekty kapitatu społecznego migrantów}

Rozważania na temat kapitału społecznego imigrantów należy rozpocząć od ustalenia definicji, które posłużą za wstęp do dalszej analizy zjawiska. Migracja jest badana w ramach różnych okresów i dyscyplin naukowych na gruncie nauk socjologicznych, ekonomicznych oraz geograficznych. To powoduje powstanie odmiennych, niekiedy sprzecznych ze sobą sposobów pojmowania zjawiska migracji, utrudniających odpowiedź na pytanie, kogo można uznać za migranta, a kogo nie. Dla celów niniejszej pracy definicja została zapożyczona z raportu przygotowanego przez Organizację Narodów Zjednoczonych (ONZ), uznającą migranta za osobę, która zmienia miejsce stałego pobytu w celu osiedlenia się w innym regionie na co najmniej 3 miesiące (United Nations, Department of Economic and Social Affairs, 1998, s. 9-10). Przedstawiona interpretacja pojęcia nie jest $z$ jednej strony wolna od wad, $\mathrm{z}$ drugiej zaś odróżnia ją prostota i posiadanie kluczowych dla badań elementów łączących w sobie aspekt przestrzenny oraz czasowy. Warto zaznaczyć, że zainteresowanie autorów skupia się na imigrantach międzynarodowych, co stwarza potrzebę uzupełnienia wybranej definicji o aspekt ponadgraniczny. Powstanie zróżnicowanych sposobów ujmowania zjawiska wynika z jego interdyscyplinarności, skutkującej opracowaniem wielu teorii złożonych, spoglądających z różnych perspektyw oraz wprowadzających szereg założeń (Massey i in., 1993, s. 432). 
W modelu kapitału ludzkiego autorstwa L.A. Sjaastada pokazana jest zależność decyzji migrantów, nastawionych na maksymalizację indywidualnej użyteczności, od analizy porównawczej uwarunkowań w miejscu docelowym oraz pochodzenia. W tej sytuacji dokonuje się tzw. rachunku „Za” i „przeciw” określającego szanse i zagrożenia związane z ruchem wędrówkowym. Decyzja o zmianie miejsca zamieszkania według E.S. Lee nie zawsze jest racjonalna z uwagi na brak możliwości kompleksowej oceny wad i zalet regionu docelowego (Lee, 1966, s. 49). Ponadto rachunek ten komplikują przyczyny emigracji, które są uwarunkowane zarówno czynnikami przyciągającymi, jak i wypychającymi. Decyzja o zmianie miejsca zamieszkania jest ryzykowna zwłaszcza w przypadku migracji pionierskich, w momencie, kiedy dostęp do informacji i wsparcia jest ograniczony.

W nowym miejscu pobytu przybysze są zmuszeni do odbudowania kontaktów i pozycji w społeczeństwie przyjmującym, a także uzyskania możliwości uczestniczenia w życiu publicznym oraz poszukiwania swojego miejsca na rynku pracy. Proces ten może być utrudniony z uwagi na ograniczony poziom zaufania lokalnych mieszkańców do imigrantów i na odwrót (Galanciak, Huriy, 2020, s. 156). Wykluczenie cudzoziemców z głównego nurtu społeczeństwa niekiedy wynika również z braku znajomości języka, przepisów i zwyczajów lokalnych oraz niedostosowania kwalifikacji do wymagań kraju przyjmującego.

W celu minimalizacji niepewności towarzyszącej ruchom wędrówkowym, przy jednoczesnej chęci zapewnienia wsparcia przybyszom przez społeczeństwo cudzoziemców w nowym miejscu pobytu są tworzone sieci migracyjne. Nastawione są one na pomoc kolejnym falom imigrantów, dostarczając użyteczne informacje, a także dzieląc się doświadczeniem oraz pomagając w przystosowaniu się do nowego otoczenia. Sieci migracyjne okazują wsparcie na różnych etapach zmiany miejsca zamieszkania, począwszy od planowania wyjazdu oraz wyboru regionu przyjmującego aż po ustalenie sposobów zarobkowych oraz poszukiwania miejsca pobytu. Utrzymanie takich relacji międzyludzkich łączących członków grupy społecznej i ułatwiających im wspólne działanie nie byłoby możliwe bez zaufania, wspólnych wartości oraz zasad wzajemności, które są źródłem kapitału społecznego (Putnam i in., 1993, s. 81).

Literatura przedmiotu podchodzi w różny sposób do oceny znaczenia kapitału społecznego dla imigrantów. Z jednej strony badania wskazują, że kontakty

2 Kapitał społeczny w niniejszym artykule będzie rozumiany jako „cechy organizacji społecznych, takich jak sieci, normy i zaufanie społeczne, które ułatwiają koordynację i współpracę w celu osiągnięcia obopólnych korzyści" (Putnam, 1995, s. 67). Autorzy badania zwracają szczególną uwagę na kluczowe komponenty kapitału społecznego, jakimi są zaufanie oraz zasada wzajemności, zmniejszające poziom złożoności życia codziennego (Welter, Smallbone, 2006, s. 465-475). 
wewnątrzgrupowe ułatwiają możliwości zarobkowe dla przybyszy poprzez wykorzystanie wiedzy, informacji oraz wpływów jej członków (Castiglione i in., 2008, s. 355), z drugiej zaś autorzy podkreślają wadliwość takich więzi na etapie poszukiwania zatrudnienia w kraju przyjmującym (Bolibar, 2020, s. 6). Niezaprzeczalny pozostaje fakt, że cudzoziemcy czerpią korzyści z kontaktów ze społecznością imigrantów, uzyskując dostęp do informacji i doświadczenia (Baranowska, 2020, s. 79), jak również wsparcia etnicznego w zakresie poszukiwania sposobu ekonomicznego przetrwania w nowym miejscu zamieszkania. Jedną z dostępnych możliwości zarobkowych oraz integracyjnych jest podjęcie i prowadzenie działalności gospodarczej w nowym miejscu pobytu. Przedsiębiorstwa będące własnością imigrantów często powstają w enklawach etnicznych, które zapewniają bezpieczną formę funkcjonowania, a jej poziom rozwoju jest determinowany nastawieniem społeczeństwa przyjmującego do cudzoziemców oraz poziomu wsparcia grupy etnicznej.

\section{Przedsiębiorczość etniczna jako forma aktywności gospodarczej migrantów}

Sieci migracyjne oraz grupy etniczne pełnią nie tylko funkcję selektywną, komunikacyjną oraz adaptacyjną (Osipowicz, 2002, s. 24), ale również społeczną i popytową. Mniejszości etniczne poprzez zachowanie kultury i tradycji kraju pochodzenia oraz zgłaszane zapotrzebowanie na charakterystyczne dla danego narodu produkty i usługi tworzą okazje biznesowe m.in. dla nowo przybyłych migrantów. Powstające nisze rynkowe najczęściej mają niskie bariery wejścia, lecz nie cieszą się dużym zainteresowaniem wśród lokalnej ludności między innymi z uwagi na brak znajomości preferencji potencjalnych klientów oraz możliwości oszacowania przychodów z działalności. Ponadto łatwość nawiązania współpracy z przedstawicielami wybranego narodu lub niekiedy hermetyczność otoczenia, wynikające z pochodzenia powodują, że rynek etniczny jest obsługiwany głównie przez przedstawicieli wybranej grupy społecznej. Rozwój tego segmentu jest uzależniony od liczby i dobrostanu cudzoziemców oraz posiadanego kapitału społecznego. Imigranci w nowym środowisku w celu adaptacji społeczno-ekonomicznej mobilizują swoje zasoby i podejmują próbę prowadzenia własnej działalności gospodarczej m.in. na rynku etnicznym.

Analiza literatury wskazuje, że wielu autorów uznaje przedsiębiorczość etniczną za zbiór powiązań i wzorców interakcji między ludźmi, którzy mają podobne pochodzenie narodowe lub łączą ich wspólne doświadczenia migracyjne 
(Waldinger i in., 1990, s. 106-130). Przedstawiona interpretacja podkreśla raczej komponent etniczny niż przedsiębiorczość. W kontekście niniejszych badań autorzy postanowili uzupełnić powyższą definicję o brakujące elementy wskazujące na specyficzny zakres prowadzonej działalności gospodarczej przez imigrantów na rynku etnicznym w miejscu innym niż kraj pochodzenia. Przedstawiony sposób pojmowania zjawiska obejmuje informacje dotyczące aktywności gospodarczej przybyszy, należącej i obsługującej wybraną grupę społeczną w nowym miejscu pobytu. Przedsiębiorczość imigrantów na rynku etnicznym można rozpatrywać przez pryzmat niewielkiej organizacji produktowo-usługowej, która powstaje jako szczegółowa forma ekonomicznych zachowań cudzoziemców, wspierana przez przedstawicieli grupy oraz ich rodziny. Członkowie gospodarstwa domowego często świadczą nieodpłatne usługi, które z jednej strony wpływają na możliwość obniżenia kosztów przedsiębiorstwa, z drugiej zaś dają możliwość na zdobycie doświadczenia zawodowego w kraju emigracji (Gheribi, Ejsmont, 2018, s. 364).

Za najbardziej popularne i oczywiste przykłady aktywności gospodarczej mniejszości etnicznych uznaje się działalności w obszarze gastronomii. Warto podkreślić, że nie jest to jedyny rodzaj działalności, gdyż społeczeństwo mniejszościowe poprzez zgłaszanie popytu na niszowe produkty i usługi stwarza okazje biznesowe dla rodaków, powodując, że imigranci odnajdują się również w innych branżach, takich jak kosmetyczna, odzieżowa, prasowa czy spożywcza. Każdy z tych obszarów ma bezpośredni związek z krajem pochodzenia, gdyż przedstawiciele grupy etnicznej z jednej strony dobrze znają gusty i preferencje potencjalnych klientów, z drugiej zaś strony mają bezpośredni dostęp do oryginalnych towarów oraz know-how (Aldrich i in., 1985, s. 996-1009). Ponadto czynniki, takie jak fizyczny wygląd pracowników lub język obsługi w niektórych sektorach są bardzo ważne, ponieważ dają klientom poczucie autentyczności.

Rozwój i zauważalność przedsiębiorczości etnicznej stały się przyczyną wzrostu zainteresowań naukowych, które były poświęcane m.in. przyczynom powstania tego zjawiska (Andrejuk, 2016, s. 223-253; Brzozowska, 2015). Przede wszystkim jest ono rozpatrywane $\mathrm{w}$ aspekcie kulturowym poprzez podkreślanie znaczenia kapitału ludzkiego i społecznego, które determinują zachowania przedsiębiorcze imigrantów (Borjas, 1985, s. 463-489). Badacze również opisują zjawisko jako reakcje przybyszy na zablokowane możliwości na rynku pracy (Volery, 2007, s. 30-41). W obydwu przypadkach przedsiębiorczość etniczna powstaje w ramach nieformalnych relacji i stosunków gospodarczych przedstawicieli wybranych grup społecznych jako element wzajemnego wsparcia i pomocy. W celu adaptacji i przetrwania w nowym kraju pobytu imigranci aktywnie wykorzystują więzi oraz kontakty etniczne. Zdaniem M. Granovetter 
przedsiębiorstwa etniczne funkcjonują na podstawie solidarności i zaufania, które są nieodłączną częścią sieci migracyjnych (Granovetter, 2004, s. 76-89). Autor również podkreśla, że kapitał społeczny oparty na wspólnej tożsamości etnicznej usprawnia współpracę gospodarczą cudzoziemców.

Literatura przedmiotu przedstawia szeroki zakres czynników wpływających na skłonność migrantów do przedsiębiorczości na rynku etnicznym. Wskazuje się, że przedsiębiorczość imigrantów jest determinowana zarówno okolicznościami wypychającymi (dyskryminacja na rynku pracy), jak i przyciągającymi (szanse na rynku kraju przyjmującego). Działalność gospodarcza wśród przybyszy jest stymulowana również przez znajomości przedsiębiorców o podobnym pochodzeniu, którzy mogą być nie tylko wzorem do naśladowania, ale również ułatwiać pozyskiwanie funduszy na rozwój pomysłu biznesowego. Badania wskazują, że potencjalni przedsiębiorcy imigranci w pierwszej kolejności polegają na wsparciu finansowym rodziny lub członków grupy etnicznej w postaci pożyczek lub kontraktów z wydłużonym terminem płatności (Ibrahim i Galt, 2011, s. 607-613). W porównaniu z rodzimymi przedsiębiorcami przybysze są w mniej korzystnej sytuacji pod względem szans uzyskania finansowania od banków lub innych instytucji finansowych, nie tylko z uwagi na ograniczoną historię aktywności gospodarczej w kraju przyjmującym, ale również brak wiedzy dotyczącej sposobu założenia i prowadzenia przedsiębiorstwa w nowym otoczeniu formalno-prawnym. Bariery te są szczególnie zauważalne w przypadku nowych imigrantów, którzy w celu poprawy sytuacji mają możliwość skorzystania $z$ wiedzy i wsparcia sieci migracyjnych, stanowiących kapitał społeczny, mogący mieć kluczowe znaczenie w rozwoju przedsiębiorczości imigrantów na rynku etnicznym.

Wyzwania, z którymi zmagają się imigranci w kraju przyjmującym, dowodzą, że proces adaptacji szczególnie na początkowych etapach jest mocno skomplikowany i wymaga wsparcia zarówno ekonomicznego, jak również społecznego. Głównym źródłem pomocy są przedstawiciele wybranej grupy etnicznej lub członkowie rodziny, którzy są traktowani jako bardziej wiarygodne źródło informacji niż agencje lub instytucje wspierające cudzoziemców (Fawcett, 1989, s. 671-680). Umiejętność poszukiwania informacji odnosi się do procesów poznawczych, umożliwiających uzyskanie nie tylko rady pasywnej, ale również identyfikacji potencjału w nowym miejscu pobytu migrantów. Sposób oceny szans oraz motywy, postawy i wybór branży dla prowadzenia działalności gospodarczej nie jest identyczny dla wszystkich grup imigrantów (Masurel i in., 2002, s. 238-260). Niezmienny pozostaje fakt, iż liczna grupa społeczna o podobnym pochodzeniu przyczynia się do powstania zjawiska przedsiębiorczości wśród cudzoziemców (Waldinger i in., 1990, s. 106-130). 


\section{Przedsiębiorczość etniczna białoruskich imigrantów w Polsce}

Polska należy do krajów atrakcyjnych pod względem migracji dla obywateli Białorusi, którzy na jej terytorium stanowią drugą najliczniejszą grupę imigrantów (Urząd do Spraw Cudzoziemców, 2021). Według danych Urzędu do Spraw Cudzoziemców na koniec 2020 r. ważny dokument wydany przez organ RP uprawniający do legalnego pobytu posiadało ponad 28 tys. Białorusinów. W 2020 r. przez Główny Urząd Statystyczny została pojęta próba oszacowania całkowitej liczby obywateli Białorusi zamieszkujących na terytorium Polski było to 105404 osób (Główny Urząd Statystyczny, 2020). Jako główne powody przyjazdu do Polski są uznawane cele zarobkowe, będące potwierdzeniem rosnącej liczby legalnie pracujących Białorusinów w kraju. W polskiej literaturze naukowej ekonomiczne migracje obywateli Białorusi były rozpatrywane głównie przez pryzmat podejmowanej pracy najemnej oraz analizowane z perspektywy rodzaju wybieranych zawodów, zarówno wymagających wysokich kwalifikacji, jak również nieodpowiadających posiadanym umiejętnościom.

Poddając analizie sposoby zarobkowe oraz integracyjne Białorusinów w Polsce, autorzy zidentyfikowali wzrost zjawiska prowadzenia jednoosobowej działalności gospodarczej wśród imigrantów. W dniu 6 maja 2021 r. na terytorium Rzeczypospolitej Polskiej (RP) przez cudzoziemców legitymujących się obywatelstwem białoruskim lub polskim i białoruskim zarejestrowanych było 2832 aktywnych podmiotów. Z uwagi na brak możliwości generowania danych według stanu historycznego z systemu CEIDG utrudnione jest ustalenie rocznych zmian całkowitej liczby aktywnych jednostek, natomiast dynamikę można prześledzić na podstawie liczby złożonych wniosków o założenie/ wykreślenie jednoosobowej działalności gospodarczej, którą przedstawiono na wykresie 1.

Przedstawione powyżej dane w pełni nie odzwierciedlają zjawiska przedsiębiorczości białoruskich imigrantów w Polsce z kilku powodów. Po pierwsze warto podkreślić, że dla cudzoziemców przebywających na terytorium RP są dostępne różne formy prowadzenia działalności gospodarczej, m.in. nierejestrowanej lub w ramach spółek prawa handlowego. Po drugie z uwagi na specyfikę realizowanych badań, dostępność danych oraz ograniczoną objętość artykułu autorzy postanowili ograniczyć próbę badawczą do osób prowadzących firmę w ramach jednoosobowej działalności gospodarczej, której dobór odbywał się za pomocą grup tematycznych na popularnych portalach społecznościowych (Facebook, VKontakte, Clubhouse). 
Wykres 1. Dynamika liczby złożonych wniosków o założenie i wykreślenie jednoosobowej działalności gospodarczej przez osoby legitymujące się obywatelstwem białoruskim lub białoruskim i polskim w latach 2011-2020

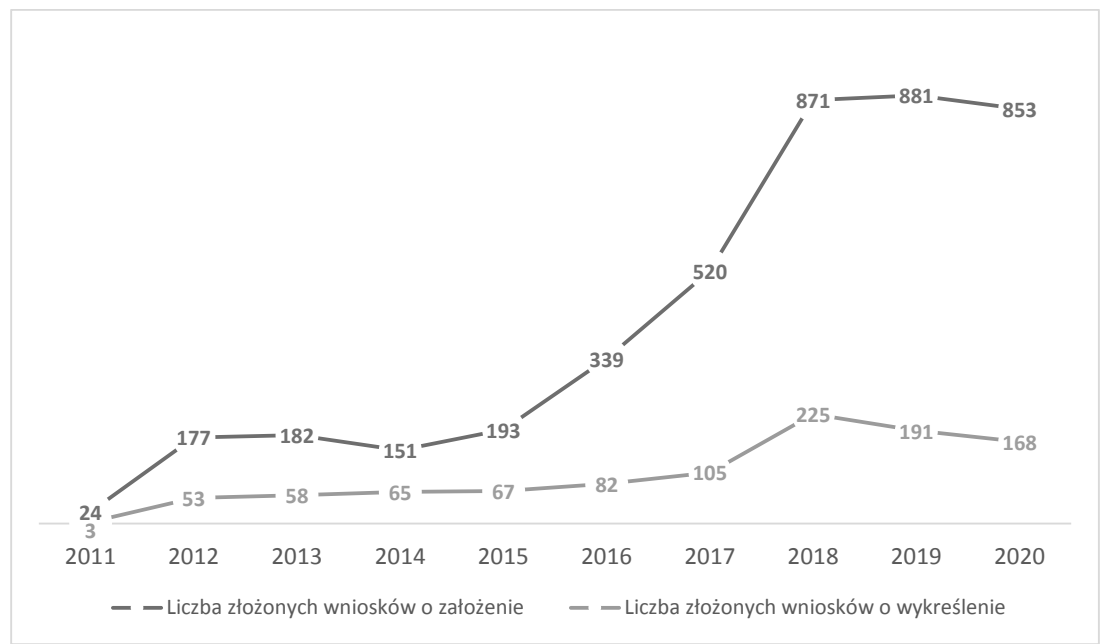

Źródło: opracowanie własne na podstawie danych Departamentu Gospodarki Cyfrowej, Ministerstwa Rozwoju, Pracy i Technologii.

W artykule ${ }^{3}$ przyjęto hipotezę badawczą, że wsparcie etniczne ma istotny wpływ na rozwój przedsiębiorczości białoruskich migrantów w Polsce. W celu zweryfikowania hipotezy przeprowadzono badania. Autorzy zastosowali metodę badawczą, jaką był pogłębiony wywiad indywidualny przeprowadzony w okresie styczeń-marzec 2021 r. Na podstawie badań pilotażowych do próby badawczej zakwalifikowano 27 legalnie przebywających na terytorium Polski imigrantów z Białorusi, prowadzących jednoosobową działalność gospodarczą na rynku etnicznym ${ }^{4}$. Scenariusz wywiadu został przygotowany zarówno w języku polskim, jak i rosyjskim ${ }^{5}$ oraz składał się z trzech bloków tematycznych umożliwiających ustalenie sposobu identyfikacji szans i pozyskiwania klientów w kraju imigracji, a także omówienie strategii rozwoju i potencjalnych zagrożeń.

${ }^{3}$ W roku 2011 dane są dostępne dla okresu sierpień - grudzień.

4 Oferowane produkty i usługi są związane $\mathrm{z}$ krajem pochodzenia, a oferta jest skierowana głównie do przedstawicieli grupy etnicznej.

5 Przed rozpoczęciem wywiadu respondenci mieli możliwość wyboru dogodnego języka komunikacji (rosyjski lub polski) w celu uzyskania największej wiarygodności pozyskiwanych odpowiedzi. Rozmowy w języku rosyjskim były tłumaczone na język polski przez Autorów badania na etapie transkrypcji wywiadów. Po dokonaniu transkrypcji nastąpił proces kodowania sporządzonych tekstów, który został wykonany samodzielnie przez Autorów badań. 
W przeprowadzonych badaniach wzięło udział 19 kobiet i 8 mężczyzn w wieku od 23 do 52 lat, mieszkających w miastach wojewódzkich (Warszawa, Kraków, Białystok i Lublin). Najkrótszy okres pobytu wśród grupy respondentów wynosił 3 lata 5 miesięcy, najdłuższy zaś 7 lat i 2 miesiące. Jako cel przyjazdu do Polski trzy osoby z badanej próby wskazały zamiar podjęcia studiów wyższych, kolejnych czternastu uczestników zadeklarowało motywy zarobkowe, natomiast pięciu respondentów określiło chęć łączenia się z rodziną, a pozostałe pięć osób odmówiło udzielenia odpowiedzi. Wśród badanych imigrantów dwudziestu trzech posiadało wykształcenie wyższe, a pozostałych czterech cudzoziemców średnie. Na podstawie uzyskanych informacji sześć osób prowadziło działalność gospodarczą w Polsce zgodnie z posiadanymi kwalifikacjami. Firmy badanych białoruskich imigrantów funkcjonowały w branży handlu detalicznego, z wyłączeniem handlu samochodami, edukacji oraz gastronomii i restauracji. Najdłuższy okres prowadzenia działalności gospodarczej wśród badanych osób wynosił 5 lat i 7 miesięcy, natomiast najkrótsze doświadczenie w zarządzaniu własnym przedsięwzięciem wynosiło zaledwie 8 miesięcy.

Po ustaleniu podstawowych informacji dotyczących respondentów autorzy poddali weryfikacji poprawność dobranej próby poprzez dokładne ustalenie rodzaju prowadzonej działalności gospodarczej oraz oferowanych produktów i usług. Drugi etap badania pozwolił wyróżnić dwie grupy przedsiębiorstw działających na rynku etnicznym.

Pierwsza z nich świadczyła usługi i dostarczała produkty charakterystyczne dla kraju pochodzenia, a głównymi odbiorcami byli klienci etniczni. W sektorze usług białoruscy imigranci prowadzili działalność związaną z opieką nad dziećmi i edukacją. Oferowane produkty były również charakterystyczne dla kraju pochodzenia, takie jak tradycyjne ciasta lub dania kuchni białoruskiej. Liczba przedsiębiorców z wyróżnionej grupy stanowiła dziewięć osób, które nie posiadały znajomości języka polskiego umożliwiającej swobodną komunikację w nowym środowisku, w tym znalezienie odpowiedniej pracy, co było jednym z powodów podjęcia własnej działalności gospodarczej w Polsce. W ramach realizowanego przedsięwzięcia białoruscy imigranci wykorzystywali wiedzę i umiejętności zdobyte w ojczyźnie. Brak możliwości posługiwania się oficjalnym językiem nowego kraju zamieszkania był wyjaśniany krótkim okresem pobytu. Powyższy fakt utrudniał poszerzenie grupy odbiorców oraz ograniczał możliwość zwiększenia podaży w Polsce. Głównym źródłem inspiracji oraz identyfikacji szans rynkowych były wskazywane sieci społecznościowe, będące zarówno platformą do poszukiwania nowych klientów, jak również promocji produktów i usług. Powodzenie tego typu przedsięwzięć w dużej mierze zależy 
od liczebności cudzoziemców oraz poziomu lojalności i zaufania konsumentów, do których dotarcie jest skuteczniejsze za pomocą tzw. marketingu szeptanego. Rekomendacje uzyskane od osób o podobnym pochodzeniu są traktowane jako wiarygodne źródło informacji oraz skłaniają potencjalnych odbiorców do nawiązania współpracy. Przedsiębiorcy potwierdzali powyższe stwierdzenie, wskazując, że nowi klienci dowiadywali się o ich działalności głównie z polecenia rodaków. Tematyka dotycząca rozwoju przedsięwzięcia dla pierwszej grupy respondentów była nieaktualna, gdyż głównym celem ich działalności było utrzymanie uzyskiwanego poziomu dochodów oraz zaspokojenie podstawowych potrzeb finansowych.

Druga wyróżniona grupa osiemnastu osób prowadziła działalność gospodarczą, oferującą produkty i usługi związane z krajem pochodzenia, ale dla większej grupy odbiorców. Klientami nie byli wyłącznie imigranci z Białorusi, ponieważ oferta była kierowana również do innych mieszkańców Polski. Cudzoziemcy funkcjonujący w tej grupie charakteryzowali się średnim stopniem integracji z ludnością kraju przyjmującego. Wskazywali oni biegłą znajomość języka polskiego, umożliwiającą swobodną komunikację, a okres pobytu w RP był dłuższy niż 3 lata. Początkowe etapy działalności gospodarczej w nowym kraju zamieszkania były podobne do grupy pierwszej, lecz chęć zwiększenia zysków z działalności oraz wzrost poziomu integracji ze społeczeństwem polskim skłoniła przedsiębiorców imigrantów do zwiększenia liczby końcowych odbiorców. Białorusini prowadzili firmy w branżach związanych z gastronomią, handlem oraz edukacją. Na początku działalności obsługiwani przez nich byli głównie imigranci z Białorusi, lecz wychodząc naprzeciw zgłaszanym potrzebom, oferta była sukcesywnie rozszerzana w celu dotarcia do cudzoziemców pochodzących z Rosji, Ukrainy i Kazachstanu, a następnie do lokalnych mieszkańców Polski. W opinii respondentów przebywający w kraju przyjmującym obywatele państw byłego Związku Sowieckich Socjalistycznych Republik (ZSSR) odczuwają pewien niedosyt oferowanych produktów. Chęć otrzymania towarów i usług związanych $\mathrm{z}$ kulturą $\mathrm{i}$ tradycjami regionu pochodzenia w nowym miejscu pobytu skłania przedsiębiorczych imigrantów do zaspokojenia rosnącego popytu. Zwiększenie grupy odbiorców i dynamiczny rozwój działalności stały się przyczyną otwarcia punktów obsługi (sklepów, restauracji, kawiarni itd.) zlokalizowanych w miejscach głównie zamieszkałych przez imigrantów oraz poszukiwania dodatkowych pracowników. Badane osoby deklarowały, że zatrudniają głównie rodaków z uwagi na podobieństwo kulturowe, większy poziom zaufania, jak również chęć pomocy w znalezieniu pracy. Dobrany personel oraz wewnętrzne otoczenie lokali dają klientom poczucie autentyczności oraz umożliwiają zanurzenie się 
w kulturze i tradycjach Białorusi. Głównym sposobem promocji działalności jest wskazywany również marketing szeptany, natomiast rola kapitału społecznego nie ogranicza się wyłącznie do grupy etnicznej. Imigranci z uwagi na swoją liczebność oraz poziom integracji z mieszkańcami Polski nie tylko reklamują białoruskie produkty i usługi, ale również pragną zapoznać społeczeństwo kraju przyjmującego $\mathrm{z}$ własną kulturą i tradycjami.

W przeprowadzonych badaniach zapytano także o motywy wpływające na podjęcie decyzji o podjęciu własnej działalności gospodarczej w Polsce. Odpowiedzi zostały zaprezentowane na wykresie 2 .

Wykres 2. Motywy podjęcia działalności gospodarczej w Polsce wśród badanych imigrantów

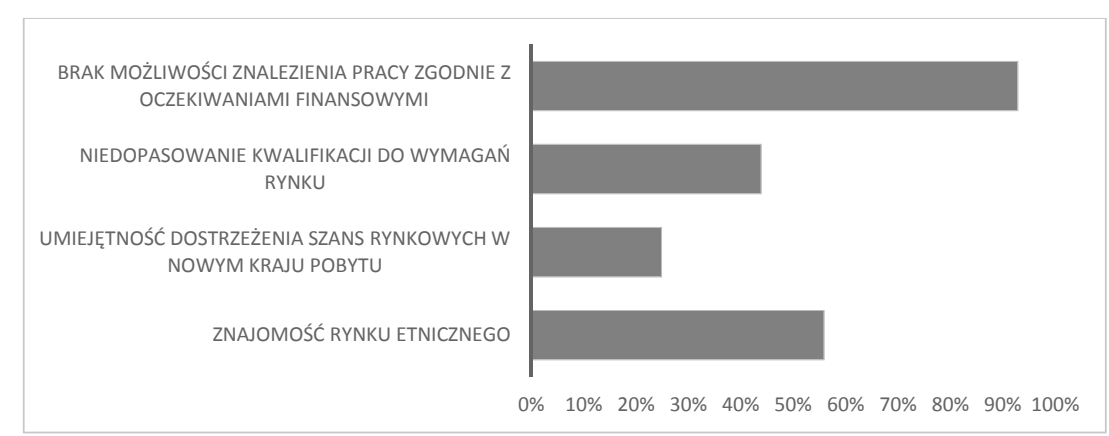

Źródło: opracowanie własne na podstawie przeprowadzonych badań.

Jako główny powód samozatrudnienia był wskazywany fakt braku możliwości znalezienia pracy zgodnie z oczekiwaniami finansowymi, czego potwierdzeniem jest wypowiedź jednego $\mathrm{z}$ indagowanych (cytat $\mathrm{z}$ zachowaniem oryginału wypowiedzi):

Na Białorusi miałam swój gabinet logopedyczny, a tu komu jestem potrzebna z tym dyplomem. Mają inne wymagania, ale też język zupełnie inny. Inaczej są ustawiane wymowy literek, musiałabym chyba sama najpierw pochodzić do logopedy. [...] i miałam tylko dwie drogi, czy coś swojego założyć, na czym się znam, czy iść sprzątać. [R8k]

Niski poziom znajomości języka polskiego oraz niedostosowanie posiadanych kwalifikacji do wymagań rynku lokalnego to kolejne powody podjęcia działalności gospodarczej wskazywane przez dwanaście osób. Przykład (cytat $\mathrm{z}$ zachowaniem oryginału wypowiedzi): 
Wszędzie wymagają znajomość języka, ale się nie dziwię. Bo jak się dogadasz nawet z szefem czy z klientem. Bo pogadać to mogę, ale już specyficzne słownictwo to tylko za pomocą google translate. [R22m]

Respondenci podkreślali również, że w tej trudnej sytuacji zawodowej prosili o wsparcie społeczność białoruskich imigrantów w Polsce, od których otrzymywali nie tylko porady, ale i pierwsze zlecenia. Komunikacja odbywała się głównie za pomocą portali społecznościowych oraz grup tematycznych na stronach internetowych, czego przykładem jest poniższa wypowiedź (cytat z zachowaniem oryginału wypowiedzi):

Jak tu przyjechałem to torciki piekłem dla przyjemności, tęskniłem za pracą jako cukiernik. A żona w międzyczasie publikowała zdjęcia na facebook i wiesz, że zaczęli zamawiać? Ciężko tu znaleźć miodowik, czy napoleon. [R2m]

Dla badanych osób jednym z argumentów przemawiającym za podjęciem działalności gospodarczej oferującej produkty i usługi etniczne jest wiedza dotycząca zapotrzebowania oraz sposobu realizacji zamówienia, czego przykładem jest udzielona odpowiedź jednego z badanych (cytat z zachowaniem oryginału wypowiedzi):

Ciężko mi powiedzieć czym się różni nasze wychowanie od tutejszego. Ale zawsze łatwiej mi się opiekować naszymi dziećmi. Bo robię wszystko z doświadczenia, jak byłam ja wychowywana, prawdopodobnie rodzice dzieci, którymi się opiekuje. Nie mam też bariery w komunikacji z rodzicami i dokładnie wiem czego oczekują. [R15k]

Umiejętność dotarcia oraz odpowiednia obsługa klientów jest uznawana za mocną stronę prowadzonego przedsięwzięcia. Respondentom trudno było odpowiedzieć na pytanie dotyczące potencjalnych zagrożeń. W opinii badanych osób zwiększająca się liczba białoruskich imigrantów w Polsce prowadzi do wzrostu atrakcyjności rynku oraz możliwości nawiązania współpracy z nowymi partnerami biznesowymi. Przykład (cytat z zachowaniem oryginału wypowiedzi):

Jest nas tu coraz więcej, ale pracy starczy dla wszystkich, aby chciało się pracować. [...] kiedyś pomagałam koleżance, którą poznałam na granicy, w przygotowaniu się do egzaminu z polskiego. Wiesz, na początku to było na zasadzie zwykłych spotkań przy kawie, a później ona mi zaproponowała zorganizować kursy dla swoich. Ona 
jest dobra w organizacji różnych rzeczy a w połączeniu z moim zamiłowaniem do nauczania powstała nasza szkoła językowa. [R1k]

Działalność cudzoziemców o innej narodowości nie stwarza dla nich zagrożenia, gdyż jest to argumentowane ograniczonym poziomem zaufania do usług świadczonych przez innych imigrantów w RP oraz brakiem możliwości odtworzenia w podobny sposób oferowanych produktów i usług. Przykład (cytat z zachowaniem oryginału wypowiedzi):

Teoretycznie wszystkiego można oczekiwać, ale ciężko mi wyobrazić, aby ktoś z naszych poszedłby po czekoladę Alionkę do sklepu z indyjskimi produktami. Nie to, że tam źle, ale nie pasuje mi jakoś. Mieszankę produktów i w markecie znajdziesz a tu się przychodzi dla autentyczności, może nawet tradycji. Można pogadać, pośmiać się po swojemu. [R4m]

Respondenci nie wykluczali możliwości powstania zagrożenia ze strony pozostałych imigrantów w Polsce, lecz w ich ocenie z tego powodu szansa utracenia klientów jest znikoma.

\section{Zakończenie}

Podsumowując przeprowadzone badanie, można stwierdzić, że dla białoruskich imigrantów w Polsce najbardziej wartościowe w podjęciu i prowadzeniu działalności gospodarczej okazało się nieformalne wsparcie udzielone przez rodaków zamieszkujących w nowym kraju pobytu. Szczególnie mocno podkreślony był fakt pomocy w rozpoznaniu szans oraz promocji oferowanych produktów i usług. Wsparcie imigrantów było przez respondentów również odczuwalne na etapach formalnej rejestracji działalności oraz wyjaśniania wszelkich wątpliwości związanych z jej prowadzeniem, w szczególności przez osoby posiadające doświadczenie w prowadzeniu firmy w Polsce. W narracjach białoruskich przedsiębiorców imigrantów został wskazany wysoki poziom zaufania konsumentów do oferowanych etnicznych produktów i usług. W związku z tym cudzoziemcy bardzo dbali o utrzymanie kontaktów w ramach sieci migracyjnej, które służyły pomocą w każdej sytuacji życiowej. Są one podtrzymywane głównie poprzez uczestnictwo w grupach tematycznych na popularnych portalach społecznościowych oraz okazanie wzajemnej pomocy. Badania również wskazały, że środowisko białoruskich imigrantów w Polsce nie jest zamknięte i podejmuje kroki 
w kierunku integracji ze społeczeństwem kraju przyjmującego. Przedsiębiorcy funkcjonujący na rynku etnicznym podkreślają dużą rolę wewnątrzgrupowego kapitału społecznego, znaczenie którego nie spada w miarę rozwoju prowadzonej działalności oraz wydłużającego pobytu w Polsce. Ponadto warto podkreślić, że przedstawione $\mathrm{w}$ niniejszym artykule badania stanowią tylko wstęp do pogłębionej analizy przedsiębiorczości białoruskich imigrantów w Polsce, m.in. w zakresie oddziaływania kapitału społecznego na rozwój zjawiska. Pozyskane dane statystyczne wskazują na istotność badanego tematu dla gospodarki kraju przyjmującego, a rosnąca liczba innych grup cudzoziemców w Polsce posłuży za podstawę do analizy zjawiska oraz uogólnienia twierdzeń.

\section{Bibliografia}

Aldrich, H., Cater, J., Jones, T., McEvoy, D., Velleman, P. (1985). Ethnic Residential Concentration and the Protected Market Hypothesis. Social Forces, 63(4), 996-1009. Andrejuk, K. (2016). Co skłania imigrantów do zakładania własnych firm? Analiza procesu samozatrudniania i rozwijania przedsiębiorstw etnicznych na przykładzie społeczności Ukraińców w Polsce. Studia Migracyjne - Przeglad Polonijny, 42(3), 223-253.

Baranowska, A.S. (2020). Pomoc i wsparcie społeczne imigrantów przebywających w Polsce. Komunikat $\mathrm{z}$ badań jakościowych [Aid and support given to immigrants in Poland]. Rozprawy Społeczne [Social Dissertataions], 14(1), 63-81.

Bolibar, M. (2020). Social Capital, Human Capital and Ethnic Occupational Niches: An Analysis of Ethnic and Gender Inequalities in the Spanish Labour Market. Palgrave Communications, 6(1), 1-9.

Borjas, G.J. (1985). Assimilation, Changes in Cohort Quality, and the Earnings of Immigrants. Journal of Labor Economics, 3(4), 463-489.

Brzozowska, A. (2015). Przedsiębiorczość imigrantów wietnamskich w Polsce. Rozprawa doktorska. Warszawa: Uniwersytet Warszawski. Pobrano z https://docplayer.pl/8849982-Przedsiebiorczosc-imigrantow-wietnamskich-w-polsce.html (12.03.2021).

Castiglione, D., van Deth, J., Wolleb, G. (2008). The handbook of Social Capital. Oxford: Oxford University Press.

Fawcett, J.T. (1989). Networks, linkages and migration systems. International Migration Review, 23(3), 671-680.

Galanciak, S., Huriy, B. (2020). Nowe media a rekonstrukcja kapitału społecznego migrantów ukraińskich na polskim rynku pracy. Studia Migracyjne - Przeglad Polonijny, 46(2), 153-178. 
Gheribi, E., Ejsmont, A. (2018). Effective Human Resources Management Practices as a Competitive Advantage Factor in Selected Examples from Foodservice Family Businesses, Przedsiębiorczość i Zarządzanie, 19(7/2), 359-374.

Główny Urząd Statystyczny. (2020). Populacja cudzoziemców w Polsce w czasie COVID-19. Pobrano z https://stat.gov.pl/statystyki-eksperymentalne/kapital-ludzki/ populacja-cudzoziemcow-w-polsce-w-czasie-covid-19,12,1.html (12.04.2021).

Granovetter, M. (2004). Economic institutions as social constructs: the scope of analysis. The Journal of Sociology and Social Anthropology, 7(1), 76-89.

Ibrahim, G., Galt, V. (2011). Explaining ethnic entrepreneurship: An evolutionary economics approach. International Business Review, 20(6), 607-613.

Kwarcińska, A. (2004). Uwarunkowania zewnętrzne jako szansa rozwoju przedsiębiorczości. W: J. Brdulak, M. Kulikowski (red.), Przedsiębiorczość stymulatorem rozwoju gospodarczego (s. 15). Warszawa: Instytut Wiedzy.

Lee, E.S. (1966). A theory of migration. Demography, 3(1), 47-57.

Massey, D.S., Arango, J., Hugo, G., Kouaouci, A., Pellegrino, A., Taylor, J.E. (1993). Theories of International Migration. A Review and Appraisal, Population and Development Review, 19(3), 431-466.

Masurel, E., Nijkamp, P., Tastan, M., Vindigni, G. (2002). Motivations and performance conditions for ethnic entrepreneurship. Growth and Change, 33(2), 238-260.

Masurel, E., Nijkamp, P., Vindigni, G. (2004). Breeding places for ethnic entrepreneurs: a comparative marketing approach. Entrepreneurship \& Regional Development, 16(1), 77-86.

Osipowicz, D. (2002). Rola sieci i kapitału społecznego w migracjach zarobkowych. Przykład Moniek (seria: Prace Migracyjne, 46). Warszawa: Instytut Studiów Społecznych UW.

Putnam, R.D., Leonardi, R. (1993). Making Democracy Work: Civil Traditions in Modern Italy. Princeton: Princeton University Press.

Putnam, R.D. (1995). Bowling alone: America's declining social capital. Journal of Democracy, 6(1), 65-78.

United Nations, Department of Economic and Social Affairs. (1998). Recommendations on Statistics of International Migration. Revision 1, Statistical Papers Series M, 58(1).

Urząd do Spraw Cudzoziemców. (2021). Raport na temat obywateli Białorusi. Pobrano z https://udsc.gov.pl/wp-content/uploads/2021/01/RAPORT-NA-TEMAT-OBYWATELI-BIALORUSI.pdf (15.03.2021)

Waldinger, R., McEvoy, D., Aldrich, H. (1990). Spatial dimensions of opportunity structures. W: R. Waldinger, H. Aldrich, R. Ward (red.), Ethnic Entrepreneurs: Immigrant Business in Industrial Societies (s. 106-130). Newbury Park: Sage Publications. 
Welter, F., Smallbone, D. (2006). Exploring the role of trust in entrepreneurial activity. Entrepreneurship Theory and Practice, 30(4), 465-475.

\section{Streszczenie}

Imigranci zagraniczni stanowią nieodłączny element Polskiej gospodarki, co wzbudza zainteresowania nie tylko polityków, ale również naukowców. Zmiana miejsca stałego zamieszkania wiąże się m.in. z potrzebą adaptacji społecznej oraz znalezienia stabilnego źródła dochodu w nowym kraju pobytu. Imigranci nierzadko korzystają z pomocy i wsparcia sieci migracyjnej, a zachowanie kultury i tradycji stwarza dla cudzoziemców okazje biznesowe. Z uwagi na doskonałą znajomość preferencji potencjalnych konsumentów działalność przybyszy jest skoncentrowana m.in. na rynku etnicznym. W artykule poddano analizie wpływ kapitału społecznego na rozwój przedsiębiorczości etnicznej wśród białoruskich imigrantów w Polsce. Artykuł został oparty na przeglądzie literatury przedmiotu, danych statystycznych uzyskanych w Ministerstwie Rozwoju, Pracy i Technologii oraz pogłębionych wywiadach indywidualnych wśród imigrantów z Białorusi prowadzących działalność gospodarczą na rynku etnicznym w Polsce.

SŁOWA KLUCZOWE: kapitał społeczny, grupa etniczna, przedsiębiorczość, imigracja.

\section{Summary}

Foreign immigrants are an integral part of the Polish economy, which arouses the interest of not only politicians but also scientists. The change of the place of permanent residence is connected, among other things, with the need for social adaptation and finding a stable source of income in the new country of residence. Immigrants often use the help and support of the migration network, and the preservation of culture and traditions creates business opportunities for foreigners. Due to the excellent knowledge of the preferences of potential consumers, the newcomers' activities are concentrated, among others, on the ethnic market. The article analyzes the impact of social capital on the development of ethnic entrepreneurship among Belarusian immigrants in Poland. The research was based on a literature review, statistical data obtained from the Ministry of Development, Labor and Technology, and in-depth individual interviews with Belarusian immigrants running a business in the ethnic market in Poland.

KEYWORDS: social capital, ethnic group, entrepreneurship, immigration.

\section{Noty o autorach}

Marta Kruhlaya - mgr; doktorantka w Katedrze Geografii Ekonomicznej Szkoły Głównej Handlowej w Warszawie; główne obszary działalności naukowej: geografia ludności, a w szczególności migracje obywateli państw z obszaru byłego ZSSR do Polski, zarządzanie zasobami ludzkimi w ujęciu branżowym; e-mail: mkruhlaya@gmail.com; ORCID: 0000-0003-1478-0557.

Marcin Molenda - dr; adiunkt w Katedrze Geografii Ekonomicznej Szkoły Głównej Handlowej w Warszawie; główne obszary działalności naukowej: zarządzanie zasobami ludzkimi w przedsiębiorstwie turystycznym; e-mail: mmolen@sgh.waw.pl; ORCID: 0000-0001-6566-7103. 